International Journal of Engineering \& Technology, $7(4.38)(2018)$ 1266-1269
International Journal of Engineering \& Technology
WPC
Website: $w w w . s c i e n c e p u b c o . c o m / i n d e x . p h p / I J E T$
Research paper

\title{
Parents' Perspectives on Quality ECCE Curriculum: Instrument Development
}

\author{
*Siti Shamsiah Sani, Hafsah Taha, Rosfizah Md Taib, Abdul Halim Masnan, Che Nidzam Che Ahmad, \\ Asmayati Yahaya, Sadiah Baharom, Saipolbahrin Ramli \& Sopia Md Yassin
}

\author{
Biology Department, Faculty Science and Mathematics \\ Universiti Pendidikan Sultan Idris 35900 Tanjong Malim \\ Perak Malaysia
}

\begin{abstract}
The aim of the study was to develop and validate the Early Childcare and Education (ECCE) Curriculum Instrument for Parents (QECCECI-P) by examining parents' perspectives on the quality of the ECCE curriculum in the Malaysian context. The items were developed based on the existing literature that examines curriculum programmes for young learners. The instrument was validated by ECCE curriculum experts. More than 350 parents who send their children to government- or non-government-funded preschools were involved in the study. The study shows that two factors are related to parents' perspectives on the quality of the ECCE curriculum: curriculum content and philosophy and core principles. The items in this instrument have factor loading values ranging from 0.479 to 0.84 . The items also have high internal consistency with the alpha reliability coefficient values for each factor, which are more than 0.9. The results indicate that the instrument is valid and reliable for measuring parents' perspectives on the quality of the ECCE curriculum in the Malaysian context.
\end{abstract}

Keywords: Curriculum, ECCE, Instrument Development.

\section{Introduction}

Research from well-established longitudinal studies has confirmed the impact of high-quality Early Childcare and Education (ECCE) programmes on a child's development (e.g., the Perry Preschool Project, the Prenatal Early Infancy Project, the Abecedarian Early Childhood Intervention, the Chicago Child-Parent Centre Programme and the Head Start Programme). As such, the provision of quality ECCE programmes is an important investment in the overall social, economic and human capital development of a country. In Malaysia, there is increasing attention, funding, capacitybuilding programmes and support in the form of national constitutions, policies, laws and legislations offered in order to provide an enabling environment for the development of ECCE. The development of ECCE programmes in Malaysia is also a result of the effort and contributions of parents, local communities, religious bodies, private entities and charitable organisations.

In ensuring the standards and provision of a firm preparatory foundation for primary schooling, the National Preschool Curriculum Standards (NPCS) were introduced and implemented in 2010 for children aged four to five years old. The implementation of the PERMATA Negara programme in 2007 and the formulation of policy related to the care and education of children aged zero to four years was an important milestone for the Malaysian ECCE. Both curricula have now been implemented in Malaysia for more than seven years, but there are only limited studies that examine parents' or guardians' perceptions of the current curriculum, particularly in Malaysia. Studies have highlighted how parents and guardians play a significant role in both the development of children's learning experiences and, in particular, in decision making regarding certain aspects of child learning such as curriculum implementation.1 However, most research has examined parental involvement in child welfare, child development, home visits and the transition programme in the ECCE programme.2-4

Thus, it is necessary to develop an instrument to gauge, in particular, parents' perceptions of the quality of the Malaysian ECCE curriculum. The findings may provide information to help develop a comprehensive framework on the quality of the ECCE curriculum in Malaysia. This evaluation would make a significant contribution towards the quality of development and learning for young children, ensuring the future of a bright young generation that could contribute to the nation's prosperity.

\section{Research Objective}

The aim of the paper is to develop a questionnaire to riculum.

\section{Literature Review}

There has been an increasing focus on early childhood education in the global context. Upon realising the importance of early childhood education for the nation's development, the Malaysian government began to enhance the quality of the ECCE curriculum through policies and legislation. Such developments are evident in the government agenda and several initiatives, including the National Key Result Areas (NKRA), the 11th Malaysia Plan, the Government Transformation Programme 
(GTP) and the Education Blueprint 2013-2025. The quality of aspects of the ECCE curriculum in Malaysia has not yet received the required attention, as the focus continues to remain largely on achieving quantitative target figures.

Family involvement in the early childhood classroom benefits children, schools and families. Family involvement encompasses the participation of the parent in the child's curriculum education.5However, a number of issues and concerns play a role in parents' perspectives when selecting an appropriate ECCE centre for their children. At present, in the absence of the system of licensing or recognition of ECCE institutions, the emerging concern is about the quality of the ECCE curriculum, assurance about the appropriateness of the learning experiences for children and the safety of the environment in which such programmes are conducted.6

The theoretical perspectives and research for children who are of preschool age and older provide a basis for comprehensively defining parental involvement in children's learning and schooling.7 On the whole, parental involvement is essential to the quality of the ECCE curriculum and this helps to broaden children's horizons, enhance social relationships and promote a sense of self-esteem and self-efficacy.8

Despite the number of children in ECCE programmes, most research concerning parental involvement focuses on families with children in the school system and the quality of the curriculum.7 Parent involvement is optimise when parents are given guidance and support in understanding child development and learning. Epstein's framework identifies six of types of parental involvement; that is, parents and teachers, as partners, share an interest in and responsibility for children.9 Both partners understand the importance of working together to promote and enhance the academic and social development of children. It is essential that the foundation for family-school quality programme partnerships is nurtured early in a child's educational experience in an effort to enhance future family-school partnerships, as well as optimise that child's educational success. 6-7

The quality of the ECCE curriculum mediates the positive benefits of attending preschool; put simply, better quality childcare is generally related to better cognitive and social outcomes for children.10 Although it has not yet been possible to establish a causal relationship between the quality of the ECCE curriculum and child outcomes, most experts are satisfied that the evidence base from many correlational studies is sufficiently convincing to advocate for the provision of a high-quality curriculum.

\section{Methodology}

A series of workshops were held to explore possible constructs and sub-constructs that could have an impact on the quality of the ECCE curriculum. Items were generated from an extensive literature review 11-16 and were also constructed based on the current Malaysian ECCE curricula, namely PERMATA and Kurikulum Standard Prasekolah Kebangsaan. Both curricula documents were used as main references in conducting lessons. The items were also generated based on existing international quality standards for ECCE such as the Standard Kualiti Prasekolah Kebangsaan17, the Guidelines for the National Quality Standard18, Ofsted Inspections of Children's Centres19 and the NAEYC Early Learning Programme Standards and Assessment Items.20

Expert evaluations of the construct validity were provided by lecturers in early childhood education from four local universities. Besides several comments that focused on obtaining parents' perspectives on 'learning by playing', the experts required no crucial amendments to the items and their respective constructs. A few experts commented on items' phrasing, grammar and spelling mistakes; these have been addressed by consulting English language experts. In addition to the experts' evaluation of construct validity, we also carried out statistical approximation efforts on the validity of the questionnaire. Exploratory factor analysis (EFA) and confirmatory factor analysis (CFA) with oblimin rotation were completed in order to extract and confirm possible factors. Items were retained based on a large factor loading $(>0.3)$ and Eigenvalue $\quad(>1.000) .21$ The reliability of the questionnaire was estimated by the Cronbach's alpha values for individual and overall constructs. This exercise was completed during the pilot test, which involved 372 samples. Items were then scrutinised and refined again before the committee decided on the constructs and the final number of items.

\section{Result}

Before the factor analysis was conducted, Bartlett's test of sphericity was carried out to examine whether the sample had equal variances. The Kaiser-Meyer- Olkin (KMO) test was then conducted to measure the

suitability of the data for factor analysis. The KMO value should be greater than 0.6 before the factor analysis is conducted.21 The Bartlett's test result is significant [Barlett's test $=7415.766, \mathrm{df}=253, \quad(\mathrm{p}<.000)]$. In this study, the KMO value was .953. The results of both tests show that the factor analysis could be carried out on the data.

The researchers used Eigenvalues and the scree test to identify the factors to be included in the instrument. First, in order to retain the number of factors, the Eigenvalues should be greater than 1.0. The second option for determining the number of factors is the scree test. The scree plot demonstrates the Eigenvalues in descending order on the y-axis and the number of factors on the $\mathrm{x}$-axis.

The plots where the steep slope is clearly levelling show the number of meaningful factors that should be included in the instrument. The factor analysis for the parents' perspectives on the ECCE curriculum began with $30 \quad$ items. The analysis indicates that 23 items can be placed under two factors that have a value greater than one. The scree plot shows two plots before it starts to level. Fig. 1 shows the scree plot.

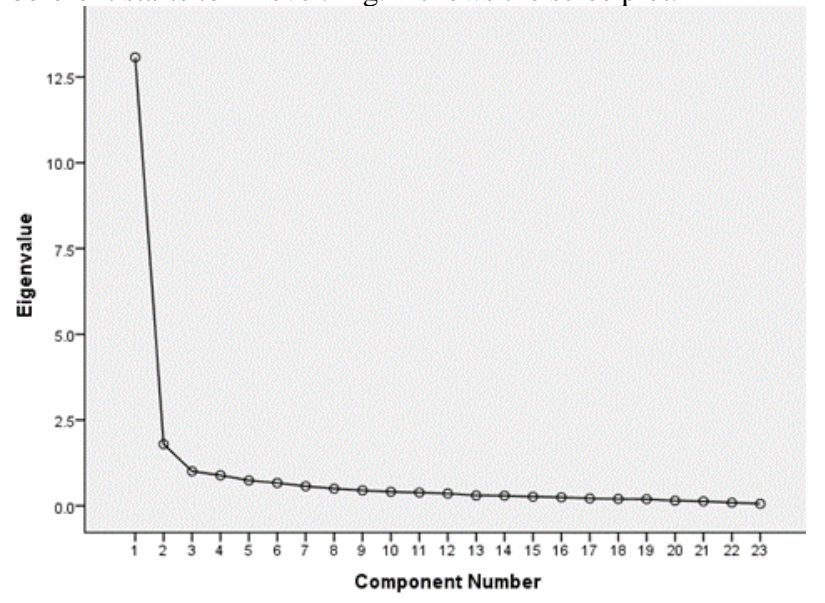

Fig.1: Factor selection using a scree plot

Based on two factors, the total variance is $64.66 \%$. The value is sufficient for the social sciences as the variance value is between $40 \%$ and $60 \%$ (Kutluca \& Özpinar, 2010).22 Each Eigenvalue and percentage of variance in the instrument are presented in Table 1. Initially, two factors were developed for the instrument. After the factor analysis, two factors remained: philosophy and core principles and curriculum content. There are 23 items grouped into two different factors with Eigenvalues greater than one. The total variance for the first factor is $56.84 \%$ and for the second factor, $7.82 \%$. 
Table 1: Eigenvalues and percentage of variance by each factor.

\begin{tabular}{|c|c|c|c|}
\hline Factor & Eigenvalues & $\begin{array}{l}\text { Percentage of vari- } \\
\text { ance for each factor }\end{array}$ & $\begin{array}{l}\text { Total per- } \\
\text { centage of } \\
\text { variance }\end{array}$ \\
\hline 1 & 13.072 & 56.84 & 56.84 \\
\hline 2 & 1.798 & 7.82 & 64.66 \\
\hline
\end{tabular}

Intially, the total number of items was 30 , but after the refinement process the items were reduced to 23 .

Seven items were removed from the instrument as the loading factor value was less than 0.3 with an Eigenvalue of less than 1.000.21 The questionnaire employed a four-point Likert scale (1=Strongly Disagree (SA), 2=Disagree (D), 3=Agree (A) and 4=Strongly Agree (SA). The instrument was written in Bahasa Malaysia and English. Bahasa Malaysia is the official first language in Malaysia, while English is the second. Table 2 shows the loading factors of each item.

Table 2: Factor loadings for a refined 23-item version of the instrument

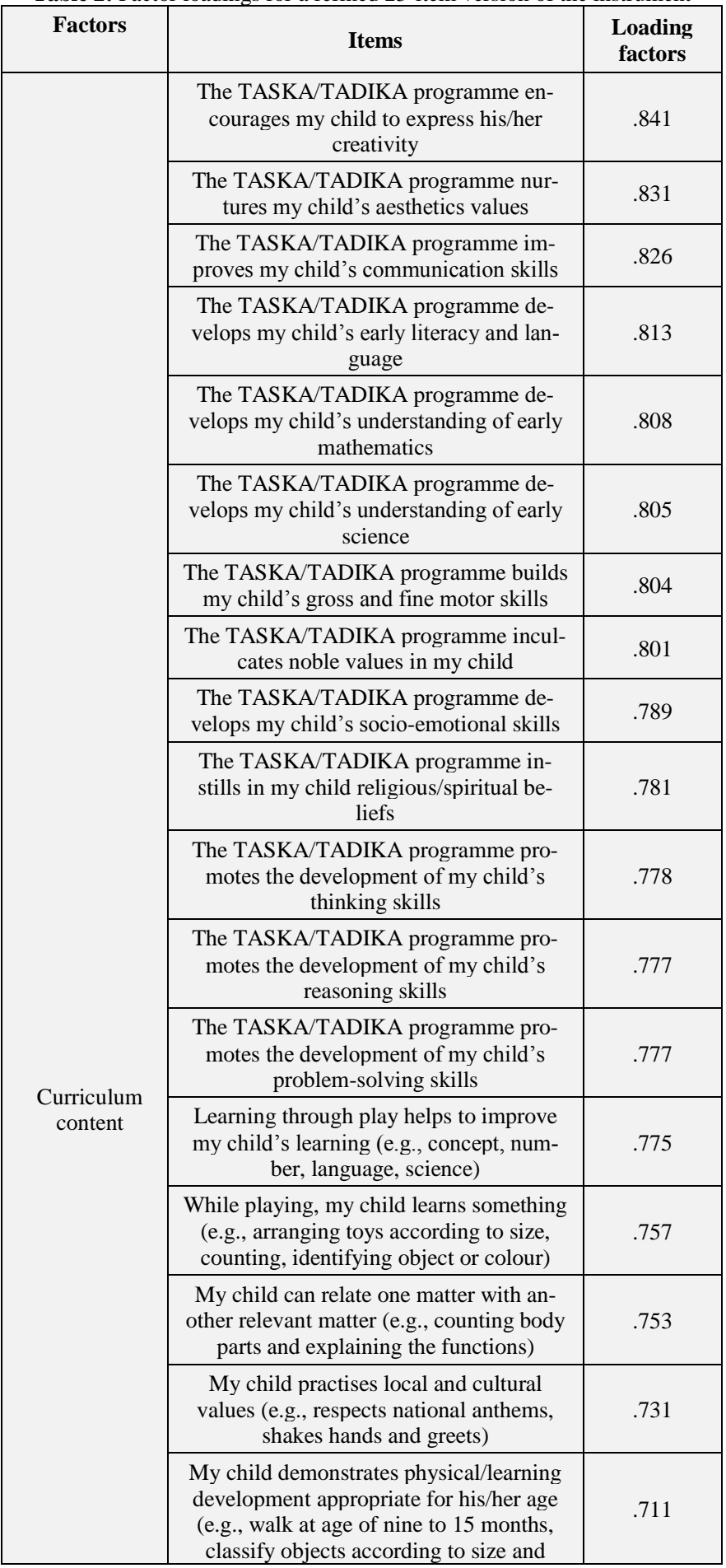

\begin{tabular}{|c|c|c|}
\hline \multirow{7}{*}{} & $\begin{array}{c}\text { colour at two to six years old) } \\
\text { My child shows the ability to use elec- } \\
\text { tronic device applications (smartphone, } \\
\text { computer and tablet) to learn something } \\
\text { (e.g., using educational applications such } \\
\text { as 'Learning Letters Puppy' and 'Draw- } \\
\text { ing Pad For Kids') }\end{array}$ & . \\
\cline { 2 - 3 } & $\begin{array}{c}\text { I am given the opportunity to take part } \\
\text { in the programme review process at my } \\
\text { child's TASKA/TADIKA }\end{array}$ & .479 \\
\hline \multirow{2}{*}{$\begin{array}{c}\text { Philosophy } \\
\text { and core } \\
\text { principles }\end{array}$} & $\begin{array}{c}\text { The philosophy of TASKA/TADIKA is } \\
\text { easy to understand }\end{array}$ & .733 \\
\cline { 2 - 3 } & $\begin{array}{c}\text { The vision of TASKA/TADIKA is easy } \\
\text { to understand }\end{array}$ & .729 \\
\cline { 2 - 3 } & $\begin{array}{c}\text { The mission of TASKA/TADIKA is easy } \\
\text { to understand }\end{array}$ & .725 \\
\hline
\end{tabular}

The relibility index (Cronbach's alpha) was evaluated on the finalised scale in order to identify the internal consistency. Alpha value closer to one indicates a greater internal consistency of the items. In this study, the alpha values show a very good reliability index as the values are greater than $0.9 .{ }^{23}$ Table 3 shows the Cronbach's alpha coeffient values for two factors that consist of 23 items.

Table 3: The Cronbach's alpha coeffient value for each factor

\begin{tabular}{|c|c|}
\hline Factors & Alpha \\
\hline Philosophy and core principles & 0.97 \\
\hline Curriculum content & 0.94 \\
\hline
\end{tabular}

\section{Discussion}

This study focused on developing a reliable and valid instrument to determine parents' perspectives of the ECCE curriculum. The instrument was created through an iterative process. Initially, the instrument encompassed 30 items and tested more than 350 samples. Based on the factor analysis, seven items were removed from the scale and 23 items were

included in the instrument after the refinement. The items were grouped into two factors: philosophy and core principles and curriculum content. The analysis indicated the instrument has good construct validity and high reliability.

The instrument can be administered easily as it consists of 23 items in two constructs. The number of items is appropriate as participants took around 15 minutes to answer them. Items in the instrument were easily understood by participants in the pilot study as it is written in Malay and English. Both languages are first and second languages spoken in Malaysia. The structure of sentences and words used in the instrument are simple. However, if participants have problems understanding the terminology, they can refer to a glossary for clarification.

The instrument can be modified and used for different stakeholders such as teachers, community members or

childcare providers. The process of adapting the instrument depends on the needs and aims of the research. However, when constructing and verifying the items, researchers should take into consideration the fact that the instrument is being developed to understand parents' perspectives on the ECCE curriculum.

\section{Conclusion}

This study has investigated the process of developing and validating an instrument to measure parents' perspectives on the ECCE curriculum. The instrument was developed based on current literature reviews of the ECCE curriculum. The questionnaire was piloted to more than 350 samples and had to withstand the vigorous validity and reliability estimation exercises. The questionnaire was found to be valid and reliable enough to be used in the main study. However, further studies could be carried 
out to refine the instrument by involving different stakeholders to create a rigorous instrument.

Acknowledgment: This research study was supported by Ministry of Finance (MOF) through the Ministry of Education (MOE) Malaysia. We thank the National Child Development Research Centre (NCDRC), Universiti Pendidikan Sultan Idris (UPSI) as the leading university in this study in collaboration with SEGi University. The title of this study is Development of Comprehensive and Integrated Model of Quality Malaysian Early Childhood Care and Education (ECCE) which comprises four projects namely; Project 1: Evaluation of Existing ECCE Programs to Improve Quality That Inform Policy, Project 2: Development of Carers-Educators' Professionalism, Project 3: Determining Contributing Factors of Quality ECCE and Project 4: Impact of EC$\mathrm{CE}$ on Human Capital Development. We thank all members of the research team who have contributed to this research. We also thank the steering committee, critical informants, teachers, parents and other stakeholders who participated in the study. Research Code for this study is 2015-0024-106-04-1

\section{References}

[1] L. Joyce, M. G. Epstein, B. S. Sanders, K. C. Simon, N. R. Salinas, Jansorn, N. R. \& F. L. Voorhis School, Family, and Community Partnerships: Your Handbook for Action (2nd ed.). CA: Thousand Oaks. (2002).

[2] Korfmacher, J., Green, B., Staerkel, F., Peterson, C., Cook, G., Roggman, L., Faldowski, R. A., \& Schiffman, R. Parent involvement in early childhood home visiting, Child Youth Care Forum, 37, pp. 171-196. (2008).

[3] Hilado, A., Kallemeyn, L., Leow, C. Lundy, M. \& Israel, M. Supporting child welfare and parent involvement in preschool programs, Early Childhood Education Journal, 39, pp. 343-353. (2011).

[4] Quintero, N. \& McIntyre, L. L. Kindergarten transition preparation: A comparison of teacher and parent practices for children with autism and other developmental disabilities, Early Childhood Education Journal, 38, pp. 411-420. (2011).

[5] Ansari, A. \& Gershoff, E. Parent involvement in head start and children's development: indirect effects through parenting, Journal of Marriage and Family, 78, pp. 562-579. (2016).

[6] Morrison, J. W., Storey, P. \& Zhang, C. Accessible family involvement in early childhood programs, Dimension of Early Childhood, 43(1), pp. 33-38. (2015).

[7] Mishra, L. Parental involvement in early childhood care education A study, International Journal of Psychology and Behavioral Sciences, 2(2), pp. 22- 27. (2012).

[8] Manz, P. H. Gernhart, A. L. Bracaliello, C. B. Pressimone, V. J. Eisenberg, R. A. Preliminary development of the parent involvement in early learning scale for low-income families enrolled in a child-development-focused home visiting program, Journal of Early Intervention, 36(3), pp.171-191. (2014).

[9] Fagbeminiyi, F. F. The role of parents in early childhood education: a case study of Ikeja, Lagos State, Nigeria, Global Journal of Human Social Science, 11(2), pp.43- 51. (2011).

[10] Moore, A. C., Akhter, S. \& Aboud, F. E. Evaluating an improved quality preschool program in rural Bangladesh, International Journal of Educational Development, 28, pp. 118-131. (2008).

[11] Centre for Early Childhood Development \& Education. Síolta: The National Quality Framework for Early Childhood Education. Retrieved from: siolta.ie/resources.php. (2012).

[12] Beaty, J. J. Observing Development of the Young Child (7th ed.) New Jersey: Pearson Education (2010)

[13] Beaty, J. J. Skills for Preschool Teachers (9th ed.). New Jersey: Pearson Education (2012).

[14] Beaty, J. J. Preschool Appropriate Practices: Environment, Curriculum, and Development (4th ed.). Belmont, Canada: Nelson Education, Ltd. (2014)

[15] Gordon, A. M. \& Browne, K. W. Beginnings and Beyond: Foundations in Early

[16] Childhood Education (7th ed.). US: Thomson Delmar Learning. (2008).

[17] Morrison, G. S. Early Childhood Education Today (9th ed.). New Jersey: Pearson Education. (2004).
[18] Ministry of Education. Instrumen Standard Kualiti Prasekolah Kebangsaan. Retrieved from: https://www.moe.gov.my/index.php/my/galeri- video-2017/3470promo-kumpulan-wang-amanah-pelajar-miskin-kwapm-2. (2017)

[19] ACECQA. National Quality Standard. Retrieved from:http://www.acecqa.gov.au/national-quality-framework/thenational-quality-standard. (2017).

[20] Ofsted Data collection for early years and childcare. Retrieved from: https://www.gov.uk/childcare-parenting/data-collection-forearly-years-and-childcare. (2017).

[21] NEAYC. NAEYC Program Standards and Accreditation Assessment Items Standard 2:Curriculum. Retrieved from: https://www.naeyc.org/sites/default/files/globallyshared/downloads/PDFs/accreditation/earlylearning/Standard\%202_Sept\%202017_0\%20\%281\%29.pdf. (2017)

[22] Pallant, J. The SPSS Survival Manual: A Step-By-Step Guide to Data Analysis Using SPSS for Windows (version 10). St Leonards, NSW: Allen \& Unwin. (2001)

[23] Kutluca, T., Arslan, S. \& Özpinar, I. Developing a scale to measure information and communication technology utilization levels, Journal of Turkish Science Education, 7(4), pp. 37 45. (2010).

[24] George, D. \& Mallery, P. SPSS for Windows Step-by-Step: A Simple Guide and Reference, 10.0 update (3rd ed.). Toronto: Allyn and Bacon. (2001). 